\title{
DIE DIGTER IN EN VAN DIE ECLOGAE1
}

\section{J. Swanepoel, PU vir CHO}

\section{INLEIDING}

Die vraag oor wat die poësie te doen het met die geskiedenis, oor hoe die verhouding tussen die wêreld van woorde en die wêreld van dade daar uitsien, is 'n probleem wat digters en denkers deur die eeue besig gehou het. Dit is 'n literatuur-filosofiese vraagstuk wat op die mees uiteenlopende wyses beantwoord kan word. Ek noem hier slegs twee ekstreme standpunte van die talryke moontlikhede. Die eerste is om 'n baie noue interaksie tussen die literatuur en die historiese, sosio-ekonomiese en politieke omstandighede waarin dit ontstaan het te poneer. Die ander uiterste is om die literatuur as iets a-histories te beskou, as iets in sigself geslote, tydloos en "universeel". 'n Interessante standpunt in hierdie verband - weliswaar as slotsin van 'n hoofstuk waarin daar op uitgebreide wyse ondersoek ingestel is na Vergilius se lewensomstandighede - is dié van die bekende Vergilius-kenner W.F. Jackson-Knight (1966:98): "Of Vergil's life as a sequence of events in history there is not much to say, and all his work for which he lived forces itself into the sequence of the few external facts. His real history is mental, a sequence and a spatial pattern in the imagination." Hy neem dan die debatteerbare standpunt in dat 'n "direkte" benadering tot Vergilius se poësie, waarin die tekste op sigself bestudeer word, veel meer belofte inhou.

Dit is teen die agtergrond van hierdie problematiek dat u my tema "Die digter in en van die Eclogae" moet beskou. My aanvanklike oogmerk met hierdie artikel was om die voorstelling wat daar in die Eclogae van die digtersanger gebied word, in jukstaposisie te plaas met die sosio-historiese posisie van die digter van die Eclogae, Publius Vergilius Maro, in die tweede helfte van die Eerste eeu voor Christus en om na te gaan of hierdie twee "verhale" met mekaar klop. Dit bly 'n langtermyndoelwit, maar sowel die omvang van die onderwerp as die kompleksiteit van die vraagstuk noop my om my aandag hier in hoofsaak te bepaal by die digter in die Eclogae en om slegs op 'n meer indirekte wyse enkele opmerkings te mak oor die digter van die Eclogae in sy sosio-historiese konteks.

In my bespreking van die voorstelling van die digtersanger in die Eclogae sal ek veral die klem laat val op die mag en onmag van die poësie en sal ek probeer aantoon hoe die digter in die genre van die pastorale poësie ingespeel het op 'n destyds kontemporêre sosio-politieke problematiek.

Oor die vraagstuk wat die sosiale funksie van die digter in die Eerste eeu voor Christus was, heers daar meningsverskil. Enersyds is daar diegene wat daarop wys dat Vergilius opgegroei het in 'n sogenaamde "poetic community" en dat hy ook lid was van 'n poëtiese gemeenskap toe hy na Rome gekom het. Hierdie digters was volgens Jackson Knight (1966:72) mense wat aktief was in die openbare lewe, sowel op politieke as militêre terrein. Hy is van mening dat, ten spyte van die invloed van die Epikuriese filosofie, poësie in hierdie tydvak minder afgeslote van die aktiewe lewe was as in die tydperk wat daaraan voorafgegaan het. Daarteenoor stel Griffin (1986:3): "When Virgil began to write, poetry at Rome might well have seemed hopelessly fragmented. ... It was the task of the poet to articulate the feelings of

1 Lesing gelewer by die Jaarvergadering van die Klassieke Vereniging van Suid-Afrika (Transvaaltak), 13 Oktober 1990. 
his people; but the situation of poetry made the task extraordinarily difficult." Hiervolgens is die probleem juis dat die poësie in hierdie tydperk sy sosiale funksie verloor het. Een van die faktore wat hierin 'n rol gespeel het, was die Aleksandrynse kunsideaal wat in hierdie stadium op die terrein van die poësie dominant was in Rome.

\section{DIE ECLOGAE AS 'N BOEK VAN SANGERS EN DIGTERS}

Die Eclogae (beskrywender getiteld die Bucolica) is deur en deur 'n digters- of sangersboek (kyk Williams 1967:12-13). Dit is reeds opmerklik in die openingsversreëls waar Meliboeus vir Tityrus soos volg aanspreek:

Tityre, tu patulae recubans sub tegmine fagi

silvestrem tenui Musam meditaris avena

"Onder 'n beuk se breë blaredak

lê jy, Tityrus, op jou rug

en dien jy op jou skrale fluit

die muse van die woud"2

En baie na aan die einde van hierdie bundel, in die tiende Herdersang ( $E_{c l}$. 10.70-72), lees ons:

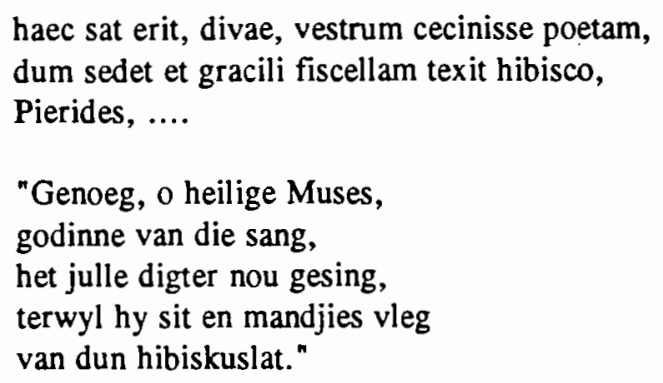

Die leser verwag natuurlik om in die pastorale poësie herdersangers aan te tref. In hierdie verwagting word hy nie teleurgestel nie: Tityrus, Meliboeus, Corydon, Menalcas, Damoetas, Daphnis en vele ander sing in hierdie gedigte hul liedere. Maar dit is nie net die herders wat sing nie. In die bladsye van die Eclogae tref die leser ook gode en mitiese figure aan wat ten nouste geassosieer is met die lied en die poësie: figure soos Apollo, Pan, Orpheus, Kalliope en Linus. Ook die natuur (sowel plant as dier) sing meermale (bv. Ecl. 1.53-58). Daarbenewens figureer ook historiese en kontemporêre digters, figure soos Gallus, Varius en Cinna, asook die poëtasters Bavius en Maevius.

Die pastorale wêreld is stereotipies 'n wêreld van eenvoud, maar selfs 'n elementêre poging om 'n sistematiek te bied van hoe die digtersanger in die Eclogae figureer, konfronteer 'n mens met die ingewikkeldheid van hierdie oënskynlike eenvoud.

Ter illustrasie van hierdie stelling noem ek twee voorbeelde. In Ecloga 6 tref ons 'n verskynsel aan wat 'n mens kan tipeer as 'n "kettingsang". 'n Hele aantal sangers word hier opeenvolgend aan die woord gestel.

2 Die Afrikaanse vertalings in hierdie artikel is deurgaans dié van N. A. Blanckenberg (1975). 
'n Tweede en komplekser verskynsel, wat vir ons tema van kardinale belang is, is die probleem van identifisering of assosiasie van bepaalde herdersangers met Publius Vergilius Maro. Naby die einde van Ecloga 5, 'n lied waarin die herdersangers Mopsus en Menalcas oor Daphnis sing, sê Menalcas aan Mopsus:

Hac te nos fragili donabimus ante cicuta; haec nos 'formosum Corydon ardebat Alexin', haec eadem docuit 'cuium pecus? an Melıboei?'

\author{
"Maar ék gee jou \\ vir eers dié tenger fluit; \\ hy het my "Die skone Alexis" en \\ "Damoetas, sê vir My" geleer".
}

Wat ons hier aantref, is werklik verrassend en toon die onhoudbaarheid daarvan aan om die wêreld van die herdersangers kunsmatig af te sny van die wêreld van die digter van die Eclogae, Vergilius. "Die skone Alexis" en "Damoetas, sê vir My" roep duidelik die aanvangsversreëls van Ecloga 2 en 3 van Vergilius op. Hierdeur word Menalcas 'n figurant van Vergilius wat hierdie gedigte geskryf het.

\title{
EXCURSUS: DIE HISTORIESE KONTEKS VAN DIE ECLOGAE
}

Teen hierdie agtergrond verskuif ek nou weer die fokus na die digter van die Eclogae, dit wil sê die digter self en die historiese konteks waarin hy die Eclogae geskryf het.

Vergilius, wat nie 'n gebore Romein was nie, wat ook nie tot die adelstand behoort het nie, maar wat nogtans ' $n$ goeie skoling geniet het (wat daarop dui dat sy familie oor genoegsame finansiële middele moes beskik het) kom in ongeveer 54 v.C. in Rome aan. In Donatus (Vita Vergiliana 16; Diehl 1911:12) lees ons die verhaal dat die jongman, wat hom klaarblyklik vir 'n loopbaan in die openbare lewe voorberei het, na slegs 'n enkele verskyning in die hof besluit het om af te sien van 'n loopbaan as regspraktisyn. Hy het verkies om hom eerder toe te lê op die bestudering van die filosofie en die skryf van poësie. Dit is ook ter sake om daarop te let dat hy onder die leermeesterskap van Siro juis die Epikuriese filosofie bestudeer het, daardie denkskool wat minder sosiaal, meer individueel en intellektueel van aard was.

Die Eclogae, die eerste van die geskrifte wat met sekerheid aan die outeurskap van Vergilius toegeskryf kan word, toon duidelik die invloed van 'n Aleksandrynse poëtika, 'n kunsrigting wat eweneens weggeskram het van die groot genres soos die epos, en gekonsentreer het op die individueel-persoonlike en op die esoteries-mitologiese (kyk Quinn 1959:26). Verder skryf Vergilius in sy vroeë loopbaan nie onder die patronaat van Maecenas (wat noue bande met Octavius, die latere Augustus, gehandhaaf het) nie, maar onder die van Gaius Asinius Pollio.

Oor die ontstaanstyd en spesifiek die publikasiedatum van die Eclogae bestaan daar heelwat dispuut (Conington 1898:21-23; Ogilvie 1984:15; Coleman 1977:18). Terwyl die meeste navorsers dit in die jare c. 42 v.C. tot 38 v.C. stel, is daar ander wat die aanvangsdatum so vroeg as 45 v.C. stel en die publikasie van die Eclogae in die finale vorm soos ons dit vandag ken in die vroeë jare van die Prinsipaat (Coleman 1977:18), so laat as 26 v.C. Die antwoord op hierdie vraag is nie net van historiese belang nie, maar raak wel deeglik die literêre interpretasie van die Eclogae. 
Ongeag wat die korrekte datums in hierdie verband is, staan dit vas dat die Eclogae, of ten minste die meeste van hierdie gedigte, geskryf is in 'n tydperk van sosiale en politieke onrus, selfs van anargie. "History has admired many Vergils" skryf Miles en Allen (1986:13) tereg. Met die historiese visie waaroor die moderne leser beskik, kan hy die tydvak waarin die Eclogae ontstaan het, netjies aan die einde van die Republiek en aan die begin van die Prinsipaat gaan plaas. En omdat Vergilius dikwels na aanleiding van die Aeneïs beskou word as die Augusteïese digter pur excellence, is die versoeking groot om die Eclogae te lees binne die raamwerk van die pax Augusta, as 't ware omgeef deur die stralekrans van die jong god wat die vrede aangebring het.

Die ontstaanskonteks sien egter heel anders daaruit. Die jare tussen die moord op Caesar in 44 v.C. en die slag van Actium in 31 v.C. wat die opperheerskappy van Octavius (die latere Augustus) verseker het, was van die mees veelbewoë in die Romeinse geskiedenis. Dit was 'n tydperk van burgeroorlog, proskripsies en groot onsekerheid. Dit was 'n tyd wat gehunker het na rus, vrede en stabiliteit, maar 'n tydperk waarin hierdie versugtinge nog nie in vervulling gegaan het nie. Griffin (1986:2) wys daarop dat nege en twintig jaar van Vergilius se bestaan van een en vyftig jaar in oorlogstyd deurgebring is, sestien daarvan in ' $n$ toestand van burgeroorlog.

Waaroor skryf 'n digter in so ' $n$ tyd van sosiale en politieke onsekerheid? Waaroor meen ons behoort hy te skryf? Die rol van die digter het deur die loop van die Romeinse geskiedenis groot veranderings ondergaan. Die Romeinse poësie in die vorm soos ons dit ken, het laat in die Romeinse geskiedenis ontwikkel. Cato die Ouere het nog in die Tweede eeu v.C. die skryf van poësie as iets nutteloos en on-Romeins gebrandmerk (kyk Quinn 1979:17). Dit het lank geduur voor Romeine van die hoër stande dit as sosiaal aanvaarbaar beskou het om hulle met die skryf van poësie besig te hou. En toe hulle dit uiteindelik begin doen het, was dit as 'n tydverdryf. Wat die skryf van poësie aanvaarbaarder gemaak het, was wanneer dit nasionale en historiese temas aangesny het (Williams 1983:6-7). Maar in die Eerste eeu v.C. het die poetae novi 'n a-nasionale rigting ingeslaan. Dit is vir my duidelik dat Romeinse digters deurgaans gespook het met die vraag oor wat die sosiale nut en funksie van die poësie was. Ons sien dit onder meer in die kompromishouding wat Horatius, in aansluiting by Hellenistiese filosowe se opvatting dat digters leermeesters en vermakers is (Williams 1983:5), enkele jare later ingeneem het, naamlik dat die poësie sowel dulce as utile moes wees (kyk Ars Poetica 343344). Die Romein het kennelik meestal baie ongemaklik daaroor gevoel om hom weg te keer van die wêreld van die daad en om sy aandag in alle erns toe te spits op die wêreld van die woord. Oor die kentering in die status van die digter in die tyd van Vergilius sal ek later iets meer sê.

Hiermee keer ek terug tot die vraag: waaroor skryf 'n digter in 'n tyd van anargie? Die jong Vergilius se keuse in hierdie verband is met die eerste oogopslag werklik verrassend. In so ' $n$ veelbewoë tydsgewrig wend hy hom tot die skryf van pastorale poësie; kies hy juis dié genre wat die heel verste verwyderd is van die alledaagse/konkrete/aktuele werklikheid! Hierby moet ook nog in gedagte gehou word dat Vergilius Rome se heel eerste pastorale digter was; dat hy geen Romeinse voorganger in hierdie genre gehad het nie (Coleman 1977:14). As moderne biograwe van die digter van Mantua gelyk het (en dit lyk vrywel seker), dan het Vergilius hom in hierdie tyd van burgeroorlog in Kampanië besig gehou met die bestudering van die Epikuriese filosofie en die skryf van herderspoësie.

Die vraag wat noodwendig gevra moet word, is of hierdie stand van sake dui op 'n ontvlugting van die harde werklikheid en op 'n ontduiking van ' $n$ burger se sosiale verantwoordelikheid. Vir iemand, wat volgens die talle lewensgeskiedenisse oor hom, skynbaar die gevolge van die 
politieke omwentelinge aan eie lyf gevoel het deur die konfiskering en onteiening van sy vaderlike erfgrond, is so iets dubbel verrassend.

\section{DIE OPSIE VAN DIE PASTORAAL}

Om lie vraag hierbo te probeer beantwoord, moet ons kortliks aandag skenk aan die tipiese kenmerke van die pastorale genre. Dit dien as aanloop tot 'n bespreking van hoe Vergilius juis die konvensies van hierdie genre verruim het.

Die pastoraal is 'n genre wat sy beslag gekry het ná die hoogbloei van die klassieke Griekse kultuur. Dit stam uit die Hellenistiese tydperk en die eerste beoefenaar daarvan as 'n literatuurgenre was Theocritus van Cos (c. 300 - c. 260 v.C.) in die Derde eeu v.C. Hierna het ook digters soos Moschus (skryf c. 150 v.C.) en Bion (skryf c. 100 v.C.) bydraes tot die verdere ontwikkeling daarvan gelewer. Alhoewel Theocritus met sommige van die pastorale sketse in sy Eidullia die grondlegger van die pastorale poësie was, toon Krautter (1983:15 n.6) myns insiens tereg aan dat Vergilius se Bucolica in die Westerse tradisie van die pastoraal "immer das eigentliche und zentrale Paradigma" vir die latere ontwikkeling van die genre was.

In die pastorale wêreld tref ons dikwels die herdersanger tussen sy ooitjies aan waar hy sy liedere sing. Dit word juis as die merkteken van die bukoliese poësie beskou dat dit die ruimte vir die lied skep (Ogilvie 1984:115-116). Alhoewel daar verwysings na labor in die gedigte voorkom, is daar in die pastoraal normaalweg 'n harmonie tussen die mens en die natuur. Die sanger bevind hom in 'n locus amoenus, of soos Berg (1974) dit mooi stel, in 'n sakro-idilliese landskap. Implisiet of eksplisiet is daar in die pastorale genre ' $n$ kontras of spanning tussen platteland en stad aanwysbaar. Wormell (1969:1) vestig die aandag op iets belangriks wanneer hy skryf: "It is in fact the poetry of escape into a world where the strains and burdens of life are eased, and existence is closer to mother earth, simpler, less bewildering or frightening, more spontaneous, more natural." Die pastoraal kan trouens beskou word as 'n teken van die gesofistikeerde stadmens se hunkering na eenvoud. Coleman (1977:8-9) wys daarop dat die drie groot temas van die pastorale genre die prag van die natuur, die blydskap en smart van die liefde en les bes die vreugde van die musiek (waarby die poësie ingereken kan word) is. Dit is 'n genre vol verskeidenheid, met 'n eiesoortige vermenging van liriese, dramatiese en narratiewe elemente.

Alhoewel Vergilius ' $n$ mate van kentering hierin teweeggebring het, is die pastorale poësie in die Oudheid as 'n genus humile beskou, Boyle (1986:4-5) se besware ten spyt. In teenstelling met die epos, daardie genre der genres waarin daar van grootse gebeure en deurlugtige figure vertel word en waarin magtige dade verheerlik word, skram die pastoraal stereotipies van sulke grootsheid weg. In aansluiting by Aleksandrynse estetika vestig dit die aandag eerder op die persoonlike dimensies van die mens se bestaan. Dat Vergilius self deeglik bewus was van hierdie genrehiërargie, blyk onder meer uit die vierde en sesde Herdersliedere ( $E c l$. 4.1-3; Ecl. 6.1-12).

Die vraag kan dus gestel word of Vergilius se keuse van die pastoraal nie sonder meer as ' $n$ ontvlugtingshandeling, as iets "escapist" beskou moet word nie. Voordat daar al te vinnig tot so ' $n$ konklusie geraak word, moet in ag geneem word dat Vergilius in belangrike opsigte ' $n$ verruiming van en ' $n$ kentering in die konvensies van die pastorale poësie bewerkstellig het. Die rigting wat Vergilius ingeslaan het, het baie daartoe bygedra dat juis hierdie werklikheidsvreemde genre 'n werktuig geword het vir samelewingskritiek, 'n funksie wat na Vergilius 'n belangrike deel van die pastorale poësie gebly het. 
Terwyl 'n mens, na aanleiding van die verlies van die geskrifte van vele van sy voorgangers in die pastorale genre, versigtig moet wees om elke nuwigheid in die Eclogae as 'n Vergiliaanse nuutskepping te beskou (kyk Coleman 1977:16-17), wil dit voorkom of Vergilius baanbrekerswerk gelewer het deur

* die inverbandstelling van die wêreld van die pastoraal met die sogenaamde "reële werklikheid"

* die wyse waarop hy die sosio-politieke problematiek van die kontemporêre samelewing op die sogenaamde tydlose wêreld van die pastoraal ingeënt het, en

* die wyse waarop prominente figure uit die wêreld van die literatuur, die militêre en politieke sfeer in die Eclogae voorgestel word.

Enkele van hierdie stellings sal weldra verder toegelig word. Voordat dit gedoen kan word, is dit nodig om met reuselaarse ' $n$ bondige sistematiese (en daarom noodwendig nie 'n literêrfunksionele nie, maar 'n algemene) verkenning te mak van die voorstelling van die digter en die poësie in die Eclogae.

\section{DIE VOORSTELLING VAN DIE DIGTERSANGER}

Sang en poësie word in die Eclogae voorgestel as deel van die normale bestaanswyse van die herdersanger. "The pastoral herdsman is ex officio a poet and the traditional image of the poet as shepherd (Hes. Th. 22-3) is now reversed" (Coleman 1977:8).

In aansluiting by die pastorale tradisie word sang en poësie voorgestel as spel. Dit sien ons mooi in die begin van Ecloga 3 waar Menalcas en Damoetas mekaar terg en treiter. Die pastorale wêreld is bekend vir die sangstryd: ' $n$ mededinging om te besleg wie die beste met die lied is. Ons kry goeie voorbeelde hiervan in Ecloga 3 en 7. Dit is heerlike woordspel, maar tegelykertyd ook 'n spel nie sonder erns nie. Dit merk ons uit Damoetas se woorde aan die beoordelaar Palaemon, waar hy hom opskerp om fyn te luister, want van so 'n kompetisie sê hy: res est non parva ( $E c l .3 .54)$. Ook in Ecloga 7 is daar sprake van 'n certamen ... magnum ( $E c l .7 .16)$, en Meliboeus stel die aanhoor van die sangstryd tussen Corydon en Thyrsis bo sy plig. Plesier voor plig, voorwaar. Verder is die sangstryd 'n stryd om oorwinning. In Ecloga 3 het ons 'n gelykopuitslag, maar in Ecloga 7 klop Corydon vir Thyrsis. En soos ek weldra sal aantoon: sukses in sang het heelwat te doen met status.

Die digtersanger bevind hom meermale in 'n beskutte ruimte: Tityrus sing onder die beskutting van 'n breë beukeboom ( $E c l$. 1.1-5); Menalcas en Mopsus maak hulle na deeglike oorweging in 'n antrum tuis voordat hulle hul liedere sing ( $E c l .5 .1-18)$; Meliboeus vertel op sy beurt hoe Daphnis hom beveel het: requiesce sub umbra (Ecl. 7.10).

Hiermee is meteen ook iets gese oor die lied en otium. Die lied gedy te midde van 'n vredige toestand. Ecloga 1 en 5 getuig hiervan. In laasgenoemde hoor ons by monde van Menalcas dat die meestersanger Daphnis lief is vir rus en vrede: amat bonus otia Daphnis (Ecl. 5.61). In dieselfde gedig word die lied vergelyk met 'n sluimering vir uitgeputte mense in 'n grasveld, met 'n verkwikking van die dors ( $E c l .5 .45-47)$.

Alhoewel dit die smart kan uitsê (en die tragiek van die liefde 'n belangrike tema in die Eclogae is) word die lied ook voorgestel as 'n vertroosting (Ecl. 9.17) en 'n uitdrukking van vreugde. In 'n vergelyking wat juis in die pastorale konteks treffend is, verseker Mopsus vir 
Menalcas in die vyfde Herdersang dat die lied van laasgenoemde die liedere van die natuur in bekoring oortref:

Quae tibi, quae tali reddam pro carmine dona?

nam neque me tantum venientis sibilus Austri

nec percussa iuvant fluctu tam litora nec quae

saxosas inter decurrunt flumina valles.

(Ecl. 5.81-84)

\author{
"Wat sal ek, \\ ja, wat sal ek \\ vir so 'n loflied gee? \\ Want so bekoor geen suidewind \\ wat saggies by sy opsteek suis, \\ geen strand waarop die branders breek, \\ geen stroom wat tuimelend \\ deur klowe tussen kranse stort."
}

In die Eclogae word die digtersangers - en dit is 'n Vergiliaanse nuwigheid - voorgestel as Arkadiërs, mense wat gereed vir sang en teensang is (Ecl. 7.4-5; kyk ook $E c l$. 10.31-33). Vir Vergilius is Arkadië nie maar 'n Griekse landstreek nie; dit is 'n landskap van die gees en die verbeelding, soos Bruno Snell (1976) in sy bekende studie aangetoon het.

Alhoewel daar al te kenne gegee is dat die pastorale wêreld 'n wereld is wat geen klas- of standverskille ken nie, is dit onmiskenbaar duidelik dat bedrewenheid in sang vir die herderdigter roem meebring. Daar is meermale mededinging oor wie die meesterdigter is. Daphnis word getipeer as 'n decus vir sy mense ( $E c l$. 5.34), en enkele van die figure word voorgestel as divini poetae. Dit geld die herderswêreld (Menalcas in Ecl. 5.45), die mitiese wêreld (Linus in $\mathrm{Ecl}$. 6.67), en ook die kontemporêre digter Gallus (Ecl. 10.17).

Die roem het egter ook sy teenkant: Menalcas poog om Damoetas as ' $n$ bespotlike sanger voor te stel ( $E c l$. 3.25-27) en die kontemporêre poëtasters Bavius en Maevius word met skerp humor afgeransel ( $E c l$. 3.90-91).

In die Eclogae tref ons nie net die woord poeta vir die digter aan nie, maar ook die term vates. Sonder om hier op die stryd tussen Dahlmann (1948) en Bickell (1951) in te gaan, kan opgemerk word dat vates (wat in sy nuwe melioratiewe sin 'n Vergiliaanse nuuttipering is) gewoonlik beskou word as 'n meer verhewe konsep van die digterskap (Newman 1967:8; Williams 1983:12). Die digter is nie meer net maker en woordambagsman nie, maar hy is nou digterprofeet, ' $n$ persoon met ' $n$ dieper insig in die gang van sake. Hier kan in die verbygaan verwys word na Silenus, die sanger-filosoof met wie ons in Ecloga 6 kennis maak. Maar oor hom later meer.

\title{
MAG EN ONMAG
}

In die Eclogae lees ons meermale van die mag van die poësie. As ons daaraan dink dat die poësie ' $n$ manier is om by wyse van woorde ' $n$ greep te kry op die werreld, dan verras dit ons nie dat verse iets magies en iets van 'n inkantasie daaraan het nie. Die magiese formule kan beskou word as ' $n$ poging om deur die korrekte gebruik van die regte woorde die wêreld na jou sin te buig. ' $n$ Mens dink in hierdie verband aan die magiese carmina en dirae (beswerings- en vervloekingsformules). En carmen dra iets van sy etimologiese verlede. Dit is 
ook die woord vir die gedig en die lied. In Ecloga 8 is die towerkunstige element opvallend aanwesig in die carmen van Alphesiboeus in sy bede om sy geliefde Daphnis uit die stad huis toe te bring. Die inkanterende refrein ducite ab urbe domum, mea carmina, ducite Daphnin klink dwarsdeur die lied van Alphesiboeus op, totdat dit aan die einde daarvan blyk dat die carmina die gewenste effek gehad het ( $E c l$. 8.64-100 en 105-109).

Die mag van die poësie is ook daarin te bemerk dat sangers deur hul lied die natuur in beweging kan bring. Dit merk ons in die vertelling oor die afbeelding op die drinkbeker wat op die spel is in die sangstryd in Ecloga 3. Daar vertel Damoetas hoe Alcimedon twee bekers gemaak het waarop hy in die middel ' $n$ afbeelding geplaas het van Orpheus en die woude wat hom volg ( $E c l .3 .44-46)$. In Ecloga 6 is daar 'n analoë verhaal. Daar word vertel hoe die Muses aan Gallus die fluite oorhandig, wat hulle tevore aan die ou man van Ascra (dit wil sê Hesiodus) gegee het. Daarmee het laasgenoemde deur sy sang die esbome vanaf die berge neergelei ( $E c l$. 6.69-72).

Die lied is egter nie net in staat om die natuurdinge in beweging te bring nie; dit kan ook die teenoorgestelde uitwerking hê. In Ecloga 8 lees ons hoe die rooikatte stupefactae is en hoe die riviere, in hul verwondering oor die lied van Damon en Alphesiboeus, terugwaarts vloei ( $E c l$. 8.1-5).

Liedere kan selfs 'n kosmiese effek he. 'n Goeie voorbeeld hiervan is die lied van Silenus in Ecloga 6. Wanneer Silenus sing, weerkaats die valleie sy liedere na die sterre toe (Ecl. 6.84).

'n Baie belangrike funksie van die poësie is dat dit groot dade kan besing. In Ecloga 4 tref ons die digtersbede aan dat hy nog mag bly leef om die dade van die wonderkind te besing. Indien dit hom beskore is, is hy oortuig dat geen van die mitiese figure hom in die lied sal kan klop nie, of dit nou Orpheus, Linus, Pan of wie ook al is; of die protosangers die hulp van hulle goddelike ouers het, en of die beoordelaars nou bevooroordeeld is of nie (Ecl. 4.53-59).

In Ecloga 6 verseker Tityrus vir Varus, 'n militêre figuur, dat daar oorgenoeg mense sal wees om sy laudes in 'n epos te besing. As pastorale digter, mooi netjies deur Apollo aan die oor gepluk toe hy self ' $n$ epos wou aanpak, hou hy hom eerder by sy pastorale lees (Ecl. 6.2-8). Ook in Ecloga 8 is dit die funksie van die poësie om groot dade te besing: tua dicere facta (Ecl. 8.8).

Die digter vervul hier die rol van lofpryser. Hierdie funksie van die lied spruit voort uit die oortuiging dat die gevleuelde digterswoord bestendigend werk, dat dit 'n persoon se naam na die sterre kan dra; kortom: dat dit onsterflikheid kan bewerkstellig. Wat opvallend is, is dat hierdie funksie, wat tradisioneel met die epos geassosieer word, nou deur die pastoraal vervul kan word, al is dit dan deur ' $n$ meer verhewe pastoraal, een wat ' $n$ konsul waardig is ( $E c l$. 4.13). Ook Varus word in Ecloga 6 verseker dat, as die pastorale gedig geslaagd is, die tamariske en die hele woud sy naam sal besing.

Die opvatting dat die poësie onsterflikheid bewerkstellig, is 'n idee wat reeds lank voor Vergilius bekend was. Tog is dit sosiologies van groot belang, want juis hieraan ontleen die digter sy krag. Hierdie funksie is op verskillende wyses in die vierde, vyfde, sesde, agste, negende en tiende herdersange te sien.

Die Eclogae het veel te sê oor die mag van die poësie, maar daar is ook 'n teenkant: die onmag van die poësie, waarop ek vervolgens in die bespreking van die Vergiliaanse verruiming van die pastoraal sal terugkom.

Met verwysing na Ecloga 1 en 9 wil ek vervolgens aantoon hoedat Vergilius die tradisionele afgeslotenheid van die pastorale genre deurbreek het; hoedat die kontemporêre historiese 
problematiek van die Eerste eeu v.C. die konvensioneel tydlose sfeer van die pastorale gedig binnegedra word. In hierdie bespreking sal gekonsentreer word op die voorstelling wat van die rol van die poësie in sulke omstandighede gebied word.

In Ecloga 1 is twee herders, Tityrus en Meliboeus, aan die woord, wat aanvanklik albei van hul grond verdryf is. Tityrus het hom egter na buite die grense van die pastorale wêreld gewend, na Rome gegaan en daar van ' $n$ iuvenis die toestemming ontvang om sy pastorale lewe voort te sit. Tityrus stel dit soos volg aan die verwonderde Meliboeus:

ille meas errare boves, ut cernis, et ipsum

ludere quae vellem calamo permisit agresti

(Ecl. 1.9-10)

"Soos jy hier sien,

laat hy my beeste toe om vry te loop

en my, om op my ruwe fluit

te speel net wat ek wil."

Hy kan sing wat hy wil, maar dit is 'n vryheid wat prekaries van aard is, iets wat hy geniet omdat daar toestemming daartoe verleen is. Die voortbestaan van sy woordbestaan geskied by grasie van 'n verteenwoordiger van die "werklike" wêreld, 'n politieke magsfiguur, iemand vir wie hy as 'n god vereer: deus nobis haec otia fecit (Ecl. 1.6).

Met die verhaal van grondverlies staan die herdersangers, Tityrus en Meliboeus, midde in die trauma van die Romeinse geskiedenis van die tweede helfte van die Eerste eeu v.C., toe die lede van die Tweede Triumviraat, na hul oorwinning oor die moordenaars van Caesar by Philippi in 42 v.C., sowat een honderd duisend oorlogsveterane moes hervestig. In hierdie proses, wat 'n hele aantal jare geduur het, is derduisende inwoners van Italië onteien en moes hulle wegtrek van die dulcia arva van hul voorvadere.

Teenoor Tityrus in sy geluksaligheid staan Meliboeus: die lydende figuur, die een op wie se lewe daar 'n brutale ingryping gemaak is deur magsfigure van buite die pastorale sfeer, die een wat - ten spyte van sy verwondering en ruimer menslikheid - uiteindelik in bitterheid moet uitroep dat hy sy lande ten behoewe van 'n barbaarse soldaat gesaai het.

Vir ons tema is die belangrike punt egter dit: in teenstelling met Tityrus wat luilekker in die skadu van skone Amaryllis sing; wat (moet) toekyk hoe Tityrus te midde van 'n singende wêreld kan voortgaan met sy eertydse lewenstyl, is Meliboeus ' $n$ figuur wat moet afskeid neem, nie net van sy vertroude landelike ruimte nie, maar ook van die woordwêreld. Strak en somber klink sy woorde op: carmina nulla canam (Ecl. 1.77).

In die verbygaan kan 'n mens opmerk dat die leser in Vergilius se uitbeelding van Meliboeus reeds iets sien van die fyn insig van die digter van Mantua in die "condition humaine", die man wat jare later sou skryf:

sunt lacrimae rerum et mentem mortalia tangunt

(Aen. 1.462)

Dit is opmerklik dat lesers geneig is om die gedig of deur die oë van Tityrus of deur die oë van Meliboeus te lees. Baie vroeëre lesers het hulle blindgestaar op Tityrus se geluksaligheid en veral op die jong god (meestal geïdentifiseer met Octavius, die latere Augustus) wat die 
wonderbare vrede aangebring het. Twintigste-eeuse lesers van na die Tweede Wêreldoorlog gaan weer die ander weg op en maak Meliboeus se situasie die sluitsteen van hul interpretasie.

Die digter van die Eclogae stel egter hierdie twee figure naas mekaar. Terwyl baie Twintigsteeeuse lesers geneig is om die Eclogae dramaties (dit wil sê met 'n oog op ontknoping) te lees, bied Paul Alpers (1979) in sy "The Singer of the Eclogues" 'n ander perspektief. Hy beskou dit naamlik as die watermerk van die pastoraal oor die algemeen en van die Vergiliaanse pastoraal in die besonder dat sogenaamde "set pieces" of tonele in 'n herdersang gejukstaponeer word sonder om gehiërargiseer te word. Juis deur hierdie jukstaposisie bewerkstellig die digter volgens Alpers 'n "suspensie". Uiteenlopende dinge word saamgedink, saamgese en naas mekaar aan die leser voorgehou, terwyl die spanning daartussen gesuspendeer en juis nie opgelos word nie.

Die slotreëls van hierdie herderslied is tekenend van hoe Vergilius, meester in die meerduidigheid, finale betekenissluiting voortdurend uitstel. Aan die einde nooi Tityrus Meliboeus uit om die nag by hom oor te bly, om te geniet van die volheid en te vertoef in ' $n$ landstreek waaroor lang skadus val. Hierdie skadus kan bloot konvensioneel wees (aangesien meerdere Eclogae eindig met 'n dagsluiting), maar dit kan ook die aankondigers van die duisternis wees (Pöschl 1964:62-63). As dit dan so is dat die harmonie herstel word, dan keer daar iets vredigs terug, maar is dit terselfdertyd ' $n$ brose vrede. Tityrus is begenadig, Meliboeus moet steeds trek. En hiermee is 'n probleem van "geregtigheid" vir die leser in die midde gelaat: Wat baat die deur Tityrus geroemde libertas as almal nie vry is nie? Wat beteken "vryheid van sang" as die ruimte waarbinne ' $n$ woordlewe moontlik is, uitgelewer is aan politieke magsfigure en nie vir almal beskore is nie?

Die situasie wat die leser vir Ecloga 9 moet konstrueer, vertoon bepaalde ooreenkomste met dié van Ecloga 1. Hier is die herder Moeris in die besit van sy grond versteur, terwyl sy sanggenoot Lycidas nie deur dieselfde ramp getref is nie. In hierdie herdersang speel nog ' $n$ herder, die afwesige meestersanger Menalcas, 'n belangrike rol. Alhoewel hy nie fisies daar is nie, word hy teenwoordig gestel deurdat Moeris en Lycidas van sy liedere sing. Hierdie herderslied is al deur navorsers soos Oppermann (1932:204) getipeer as 'n gedig waarin Vergilius op driedubbele wyse die waarde van die poësie bevraagteken. In die bestek van hierdie bespreking kan ek hier slegs die aandag vestig op Moeris se sombere maar treffende uitspraak oor die effektiwiteit van die poësie in oorlogstyd. Lycidas is verbaas om te hoor dat 'n vreemdeling as possessor die voormalige bewerkers van die land opdrag gegee het om te trek. Hy het dan gehoor dat Menalcas die pastorale ruimte waarin die herders geleef het, met sy liedere gered het (omnia carminibus vestrum servasse Menalcan (Ecl. 9.10)).

Hierop is Moeris se droewe antwoord:

Audieras et fama fuit; sed carmina tantum nostra valent, Lycida, tela inter Martia quantum

Chaonias dicunt aquila veniente columbas.

(Ecl. 9.11-13)

"Jy het reg gehoor;

die storie het hier rondgegaan;

maar, Lycidas,

ons poësie in oorlogstyd 
beteken net soveel

as, soos hul sê,

die orakelduiwe van Chaonië

wanneer die arend kom."

Hier tref die leser ' $n$ ve.dere variant van die tipies Romeinse woord-daad-digotomie aan. Daar word iets gesien van die magteloosheid van die poësie in 'n tydvak van oorlog. Die lied alleen kan die mens in sy nood nie red nie. Verskeie outeurs, veral Boyle (1986:29), bemerk hierin 'n absolute sinisme oor die poësie. Ook Oppermann beskou dit as Vergiliaanse vertwyfeling oor die waarde van die poësie, terwyl Büchner (1955:1241) ' $n$ baie fyn punt probeer maak wanneer hy argumenteer dat dit nie as 'n twyfel aan die "Wert" van die digterlike beskou moet word nie, maar eerder 'n besef van die "Wirkunglosigkeit" daarvan teenoor brutale mag. Hieraan voeg hy boonop die vraag toe of iemand so naïef kan wees om iets anders te verwag of om te dink dat die toestand in die toekoms sal verander.

Die somber woorde van Moeris is nie die begin en einde van die voorstelling van die poësie in Ecloga 9 nie. Daar kan egter hier nie verder ingegaan word op die gedig wat in die woorde van Klingner (1967:155) tussen onheil en hoop sweef nie. Daar kan slegs gewys word op die groter optimisme van Lycidas, wat sy bes probeer om Moeris oor te haal tot sang. Hier kan 'n mens opmerk dat Moeris se afwysing van die poësie nie so kategories is as dié van Meliboeus in Ecloga 1 nie. Waar laasgenoemde die volstrekte stelling carmina nulla canam gemaak het, sluit Moeris nie die moontlikheid van die lied in die toekoms uit nie. Eers moet daar egter gedoen word wat voorhande is; die poësie kan wag vir later:

Desine plura, puer, et quod nunc instat agamus. carmina tum melius, cum venerit ipse, canemus.

(Ecl. 9.66-67)

"Skei uit, jongman;

laat ons eerste doen wat eerste kom.

Ons sal ons liedjies beter sing, wanneer Menalcas self hier kom."

Die tema van die mag en onmag van die poësie loop soos 'n goue draad deur die Eclogae. Ek volstaan met die vermelding van twee beduidende voorbeelde. Die voorstelling van Gallus in Ecloga 10 toon aan hoe sy naam deur die poësie groots gemaak sal word, maar vir hierdie figuur, onder die tirannie van Amor, bekoor gedigte nie meer nie (nec carmina nobis / ipsa placent (Ecl. 10.62-63)). Ook Ecloga 6 het iets besonders wat my as leser bybly: Silenus, die wyndeurdrenkte digterfilosoof sing oor grootse en magtige temas, sy lied styg na die sterre, maar hy doen dit as ' $\mathrm{n}$ geboeide digter.

\section{ET TU}

Om hierdie tema van die mag en onmag van die poësie tot sy reg te laat kom, sou daar verder nog aandag geskenk moes word aan die voorstelling van kontemporêre figure uit die politieke, militêre en literêre sfeer in hierdie bundel. Daar sal gepoog moet word om die voorstelling van die digter en die poësie in die Eclogae in verband te bring met die konkrete sosiale werklikheid waarin die digter in die Eerste eeu v.C. geleef het. Veral 'n verkenning van die aard en invloed van literêre patronaat in die globale totstandbrenging van die literatuur sal in so 'n ondersoek 
aandag moet geniet. Ook die vraag na die rol wat taal speel in die daarstelling van 'n simboliese universum, in die sogenaamde "social construction of reality", verg 'n indringende bespreking (kyk Berger \& Luckmann 1984).

Dit is duidelik dat Vergilius op 'n verrassende wyse die netjiese skeiding tussen die idille en die "werklike wêreld" opgehef het. Alpers (1979:173) maak die stelling: "The hallmark of the Eclogues is the security and poise with which Vergil grasps the diversities and ambiguities of human experience." Of Vergilius se ideologiese posisie as ontvlugtend of as betrokke getipeer moet word, laat ek aan u oor. Want, die probleem van die mag en onmag van die poësie in 'n tyd van anargie, is nie net dié van Vergilius nie. Dit sal Suid-Afrikaanse klassici in die Twintigste eeu in 'n tydvak van onstabiliteit en die verbygaan van 'n ou orde seker maar al te deeglik besef.

\section{BIBLIOGRAFIE}

Alpers, P. 1979. The singer of the Eclogues: a Study in Virgilian pastoral. Berkeley: University of California Press.

Berg, W. 1974. Early Virgil. London: Athlone Press.

Berger, P. and Luckmann, T. 1984. The social construction of reality. A treatise in the sociology of knowledge. Penguin Books.

Bickell, E. 1951. Vates bei Varro und Vergil. Rheinisches Museum fur Philologie, N.F. LXXXIV:257-314.

Blanckenberg, N.A. 1975. Vergilius. Landelike poësie. Bucolica. Georgica. Kaapstad: Haum.

Boyle, A.J. 1986. The Chaonian dove. Studies in the Eclogues, Georgics, and Aeneid of Virgil. Leiden: Brill. (Mnemosyne Supplementum nonagesimum quartum.)

Büchner, K. 1955. P. Vergilius Maro, der Dichter der Römer. In: Paulys Realencyclopädie der Classischen Altertumswissenschaft. Bd. VIII.A 1. Stuttgart: Alfred Druckenmuller Verlag, 1021-1264.

Conington, J. and Nettleship, H. (eds.) 1898. The works of Virgil. Vol. 1. Eclogues and Georgics, 5 th edition revised by F. Haverfield. London: Bell.

Coleman, R. (ed.) 1977. Vergil. Eclogues. Cambridge: University Press.

Diehl, E. (red.) 1911. Die Vitae Vergilianae und ihre antike Quellen. Bonn: A. Marcus und E. Weber's Verlag.

Garber, K. 1976. Vorwort. In: Garber, K. (red.), Europdische Bukolik und Georgik. Darmstadt: Wissenschaftliche Buchgesellschaft, vii-xxii. (Wege der Forschung, CCCLV.)

Grant, M. 1958. Roman literature. Penguin Books.

Griffin, J. 1985. Latin poets and Roman life. London: Duckworth.

Griffin, J. 1986. Virgil. Oxford: University Press.

Jackson Knight, W.F. 1966. Roman Vergil. Penguin Books. 
Klingner, F. 1964. Virgils erste Ekloge. In: Klingner, F. Studien zur griechischen und römischen Literatur. Zürich: Artemis Verlag, 225-246.

Klingner, F. 1967. Virgil. Bucolica. Georgica. Aeneis. Zürich: Artemis Verlag.

Krautter, K. 1983. Die Renaissance der Bukolik in der lateinischen Literatur des XIV. Jahrhunderts: von Dante bis Petrarca. München: Wilhelm Fink Verlag. (Theorie und Geschichte der Literatur und der Schönen Künste, 65).

Miles, G.B. and Allen, A.W. 1986. Vergil and the Augustan experience. In: Bernard, J.D. (ed.) Vergil at 2000. Commemorative essays on the poet and his influence, 13-42. New York: AMS Press. (Ams Ars Poetica, 3).

Newman, J.K. 1967. The concept of Vates in Augustan poetry. Bruxelles: Latomus Revue D'Études Latines.

Ogilvie, R.M. 1984. Roman literature and society. Penguin Books.

Opperman, H. 1932. Vergil und Oktavian. Zur Deutung der ersten und neunten Ekloge. Hermes, LXVII, 197-219.

Otis, B. 1964. Virgil, a study in civilized poetry. Oxford: Clarendon Press.

Page, T.E. (ed.) 1969. P. Vergili Maronis Bucolica et Georgica. London: Macmillan.

Pöschl, V. 1964. Die Hirtendichtung Virgils. Heidelberg: Carl Winter.

Quinn, K. 1959. The Catullan revolution. Melbourne: Melbourne University Press.

Quinn, K. 1979. Texts and contexts. The Roman writers and their audience. London: Routledge \& Kegan Paul.

Snell, B. 1976. Arkadien. Die Entstehung einer geistigen Landschaft. In: Garber, K. (red.) Europalsche Bukolik und Georgik. Darmstadt: Wissenschaftliche Buchgesellschaft, 1443. (Wege der Forschung, CCCLV).

Williams, G. 1983. The nature of Roman poetry. Oxford: Oxford University Press.

Williams, R.D. 1967. Virgil. Oxford: Clarendon Press. (Greece \& Rome; New Surveys in the Classics, 1).

Wormell, D.E.W. 1969. The originality of the Eclogues. In: D.R. Dudley (ed.) Virgil. London: Routledge \& Kegan Paul, 27-66. 